(C) С.М. Василюк, А.Г. Шевчук, В.В. Іванина, В.І. Гудивок, А.І. Гуцуляк, В.С. Осадець, 2018

УДК 616-089+616.37-002+616-053.9

\title{
Хірургічне лікування гострого біліарного панкреатиту
}

\author{
С.М. Василюк, А.Г. Шевчук, В.В. Іванина, В.І. Гудивок, А.І. Гуцуляк, В.С. Осадець \\ surifnmu@gmail.com
}

Івано-Франківський наиіональний медичний університет, Івано-Франківськ

\section{Реферат}

Вступ. Незважаючи на широке поширення поєднаного ураження біліарної системи і підшлункової залози, чимало питань тактики лікування залишаються невирішеними. Не викликає сумнівів, що адекватне лікування цієї патології повинно поєднувати хірургічну і консервативну складові, які будуть визначатися особливостями перебігу патологічних процесів у жовчовивідних протоках і в підшлунковій залозі.

Матеріали та методи. Проведено клінічне обстеження і лікування 126 пацієнтів з гострим біліарним панкреатитом. Чоловіків було $32(25,4 \%)$, жінок - 94 (74,6\%). У 65 пацієнтів 3 гострим біліарним панкреатитом був ізольований холецистолітіаз (перша група). У 35 пацієнтів було діагностовано дрібні конкременти у різних відділах спільної жовчної протоки, які не спричиняли обтурації загальної жовчної протоки (друга група). У 26 пацієнтів діагностували обтурувальні конкременти спільної жовчної протоки, в тому числі - вклинені у великий дуоденальний сосок (третя група).

Результати досліджень та їх обговорення. Клінічна симптоматика, показники біохімічного аналізу крові, підвищення $\alpha$-амілази, ліпази, панкреатичної $\alpha$-амілази та позитивний АСТІМ Pancreatitis тест дозволяли встановити попередній діагноз гострого панкреатиту. Ультразвукове дослідження (УзД) оцінювало зміни у підшлунковій залозі, однак не завжди повноцінно характеризувало стан позапечінкових жовчних протоків. Для повноцінної характеристики патології спільної жовчної протоки застосовували магнітно-резонансну томографію (МРТ), що дозволяло чітко встановити генез гострого біліарного панкреатиту. На першому етапі лікування всі діагностично-лікувальні заходи виконували впродовж 24 годин. У 80,0 \% пацієнтів першої групи на УЗД були встановлено відсутність патологічних включень у спільній жовчній протоці. У 20,0 \% пацієнтів проводили МРТ. 25,7 \% пацієнтів другої групи потребували застосування МРТ, а 74,3 \% - транспапілярної ендоскопічної рентгенографії. У третій групі тільки у 7,7 \% УЗД було ефективним. Інші пацієнти цієї групи для верифікації причини гострого біліарного панкреатиту потребували застосування інших методів променевої діагностики. Впродовж 24 годин лапароскопічна холецистектомія (ЛХЕ) була виконана у 49 пацієнтів $(75,4$ \%) першої групи. У хворих другої і третьої груп проводили ендоскопічну діагностику і ревізію позапечінкових жовчних шляхів з наступним проведенням ЛХЕ впродовж 24 годин. У 12 (9,5\%) виникали ускладнення, пов'язані з несприятливим перебігом запального процесу в підшлунковій залозі та перипанкреатичній клітковині. У 2 хворих першої групи, 3 - другої та 2 - третьої діагностували формування несправжніх панкреатичних кіст. Враховуючи їхній сприятливий перебіг та відсутність лабораторних та клінічних даних за їхнє інфікування, цим пацієнтам рекомендували в подальшому динамічне спостереження в амбулаторних умовах. У 5 хворих формувались абсцеси заочеревинного простору (у 3 другої групи та у 2 - третьої).

Висновки. Діагностична тактика при гострому біліарному панкреатиті повинна включати: визначення активності ліпази, $\alpha$-амілази, панкреатичної $\alpha$-амілази, АСТІМ Рancreatitis тест та МРТ. У пацієнтів з гострим біліарним панкреатитом необхідно дотримуватися активної хірургічної тактики, що передбачає ЛХЕ при холецистолітіазі та ендоскопічну транспапілярну декомпресію спільної жовчної протоки при холедохолітіазі, в межах 24 годин перебування пацієнта у хірургічному відділенні.

Ключові слова: гострий панкреатит, діагностика, лікування, холецистектомія

Surgical treatment of acute biliary pancreatitis

Vasyliuk S.M., Shevchuk A.H., Ivanyna V.V., Hudyvok V.I., Hutsuliak A.I., Osadets V.S.

Ivano-Frankivsk National Medical University, Ivano-Frankivsk

\section{Abstract}

Introduction. Despite the widespread of associated damage of the biliary system and the pancreas, a lot of issues of treatment tactics remain unresolved. There is no doubt that an adequate treatment of this pathology should combine the surgical and conservative components which will be determined by the peculiarities of the course of pathological processes in the bile ducts and in the pancreas.

Materials and methods. A clinical examination and treatment of 126 patients with acute biliary pancreatitis have been performed. Men were 32 (25.4\%), women - 94 (74.6\%). There was isolated cholecystolithiasis in 65 patients with acute biliary pancreatitis (group 1). 35 patients were diagnosed small concrements in different parts of the common bile duct, which did not cause obstruction of the common bile duct (group 2). 26 patients were diagnosed obturating concretions of the common bile duct, including - impacted into a large duodenal papilla (third group).

Results and their discussion. Clinical symptomatology, biochemical blood count, elevation of $\alpha$-amylase, lipase, pancreatic $\alpha$-amylase, and positive ACTIM Pancreatitis test allowed us to establish a preliminary diagnosis of acute pancreatitis. Ultrasound examination evaluated changes in the pancreas, but did not always fully describe the state of extrahepatic bile ducts. Magnetic resonance imaging (MRI) was used to fully characterize the pathology of the common bile duct, which made it possible to clearly identify the genesis of acute biliary pancreatitis. At the first stage of treatment, all diagnostic-therapeutic measures were performed during 24 hours. The absence of pathological inclusions in the common bile duct was determined in $80.0 \%$ of patients of group 1 using ultrasound examination. MRI was performed for $20.0 \%$ of patients. $25.7 \%$ of patients of group 2 needed MRI, and $74.3 \%$ - transpacillary endoscopic radiography. The ultrasound examination was effective only in $7.7 \%$ of patients of group 3 . Other patients in this group to verify the cause of acute biliary pancreatitis required the use of 
other methods of radiotherapy. During 24 hours, laparoscopic cholecystectomy (LCE) was performed in 49 patients (75.4\%) of group 1. Patients of groups 2 and 3 were performed endoscopic diagnostics and revision of extrahepatic biliary ducts, followed by LCE during 24 hours. $12(9.5 \%)$ patients had complications related to the unfavorable course of the inflammatory process in the pancreas and peripanecratic tissue. The formation of false pancreatic cysts was diagnosed in 2 patients of group 1 , in 3 patients - group 2 and in 2 patients - group 3. Taking into account their favourable course and the absence of laboratory and clinical data for their infection, these patients were recommended to follow dynamic observation in the outpatient settings. Abscesses of retroperitoneal space developed in 5 patients (group 2 - in 3 patients and group 3 - in 2 patients).

Conclusion. Diagnostic tactics in acute biliary pancreatitis should include: determination of the activity of lipase, $\alpha$ amylase, pancreatic $\alpha$-amylase, ACTIM Pancreatitis test and MRI. Active surgical tactics involving LCE should be used in patients with acute biliary pancreatitis in cholecystolithiasis, and also endoscopic transpasillary decompression of the common bile duct in choledocholithiasis, within 24 hours of patient's stay in the surgical department.

Key words: acute pancreatitis, diagnosis, treatment, cholecystectomy

Вступ. Тактика лікування хворих на гострий біліарний панкреатит визначається низкою чинників, серед яких найбільш важливими $\epsilon$ клінікоморфологічна форма, тяжкість стану хворого, етіотропний фактор захворювання та ін. [1]. Незважаючи на широке поширення поєднаного ураження біліарної системи і підшлункової залози, чимало питань тактики лікування залишаються невирішеними. В доступній літературі ми не виявили єдиного алгоритму лікування гострого біліарного панкреатиту. Поряд з цим, не викликає сумнівів, що адекватне лікування цієї патології повинно поєднувати хірургічну і консервативну складові, які будуть визначатися особливостями патологічних процесів у жовчовивідних шляхах і в підшлунковій залозі [2].

Аналізуючи сучасні хірургічні підходи до лікування гострого біліарного панкреатиту, нами було виділено декілька напрямків. Ряд дослідників вказують, що ургентне операційне втручання показане при клінічних ознаках перитоніту, деструктивного холециститу, неефективності консервативної терапії та при наростанні ознак інтоксикації. В інших випадках рекомендують проводити консервативну терапію. Після ліквідації клініки гострого панкреатиту і дообстеженні пацієнта проводиться планове оперативне лікування патології біліарної системи. Цю тактику обгрунтовують нижчою частотою розвитку небезпечних гнійних і поліорганних ускладнень [3].

Поряд з цим, у літературі існує думка про доцільність більш активного і раннього оперативного втручання $[4,5]$. Дослідники вказують, що наявність гострого біліарного панкреатиту є показом до термінової операції, яку необхідно виконувати ендоскопічно. Об'єм і характер операції повинен бути суворо аргументований, а лікування може бути успішне тільки в тому випадку, коли видаляється патологічне вогнище (жовчний міхур, конкременти) і створюються умови для безперешкодного відтоку жовчі $[6,7]$.

Мета дослідження. Оцінити ефективність активної хірургічної тактики у пацієнтів 3 гострим біліарним панкреатитом в залежності від локалізації конкрементів у різних відділах жовчновивідної системи.

Матеріали та методи. Нами проведене клінічне обстеження і лікування 126 хворих на гострий біліарний панкреатит. Серед обстежених пацієнтів чоловіків було 32 (25,4 \%), жінок - 94 (74,6\%). Критеріями включення хворих в дослідження були: вік від 18 років, клінічні та інструментальні ознаки гострого панкреатиту, наявність в анамнезі холелітіазу або встановлення цього діагнозу на час поступлення пацієнта в стаціонар. Критеріями виключення були: медикаментозний, вірусний, ятрогенний панкреатит, тяжка хронічна ниркова дисфункція (MDRD $\leq 30$ мл/хв), клас 2 чи вище хронічної серцевої недостатності за NYHA, кисневозалежне хронічне обструктивне захворювання легень, цироз печінки, тяжка анемія, злоякісні пухлини, годування грудьми чи вагітність, тяжкі вроджені чи набуті імунодефіцитні стани.

Виходячи $з$ даних об'єктивного обстеження, результатів лабораторних та інструментальних досліджень, нами було виділено три групи хворих. До першої групи увійшли 65 хворих на гострий біліарний панкреатит, у яких спостерігався ізольований холецистолітіаз. Серед них у 42 був діагностований гострий калькульозний холецистит, у 23 - хронічний калькульозний холецистит. Другу групу склали 35 пацієнтів з гострим біліарним панкреатитом, у яких було верифіковано наявність дрібних конкрементів у різних відділах жовчовивідних шляхів, які не спричиняли обтурації загальної жовчної протоки. Серед цих хворих у 14 в анамнезі була виконана холецистектомія. Двадцять шість хворих сформували третю групу. У них були верифіковані обтурувальні конкременти спільної жовчної протоки, в тому числі вклинені у великий дуоденальний сосок. Серед них у семи був відсутній жовчний міхур, в результаті проведеної в анамнезі холецистектомії.

Результати досліджень та їх обговорення. Специфічна клінічна симптоматика, оцінка показників біохімічного аналізу крові, підвищення $\alpha$-амілази, ліпази, панкреатичної $\alpha$-амілази та позитивний $\mathrm{AC}$ TIM Pancreatitis тест дозволяли встановити попередній діагноз гострого панкреатиту. Трансабдомінальне УЗД дозволяло оцінити зміни збоку підшлункової залози, однак не завжди повноцінно характеризувало стан позапечінкових жовчних протоків. Для повноцінної характеристики загальної жовчної протоки ми застосовували магнітно-резонансну томографію (МРТ) панкреатобіліарної зони, що дозволяло чітко встановити генез гострого біліарного панкреатиту.

На першому етапі лікування (фаза панкреатичного шоку) всі діагностично-лікувальні заходи вважали за доцільне виконувати впродовж 24 годин 3 часу поступлення пацієнта в стаціонар. У хворих першої групи після проведення передопераційної консервативної терапії, спрямованої на зниження ферментної агресії та пов'язаних з нею запальних змін в підшлунковій залозі, попередження інфікування парапанкреатичної клітковини та корекцію супутньої патології і системних змін, спричинених панкреатитом. 

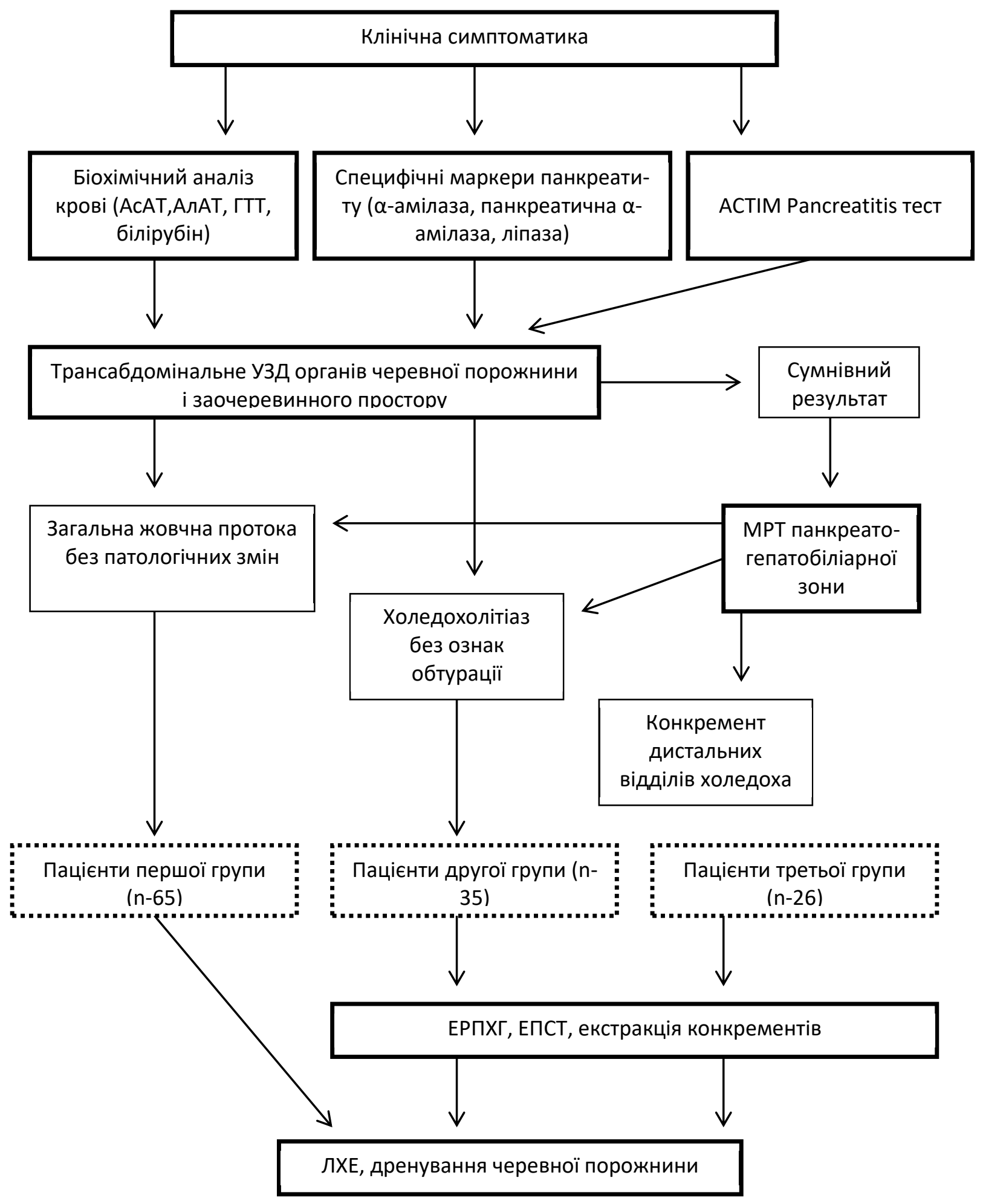

Периопераційна консервативна терапія

Рис. 1. Діагностично-лікувальний алгоритм у пацієнтів із гострим біліарним панкреатитом

Найбільш практично важливими специфічними лабораторними тестами гострого біліарного панкреатиту була оцінка рівня в крові $\alpha$-амілази, панкреатичної $\alpha$-амілази та (у частини пацієнтів)
ACTIM Pancreatitis тест. Підвищення активності ліпази в сироватці крові, як діагностичного маркеру, оцінювалось тільки на фоні підвищення амілази в сироватці крові та сечі. Одразу при поступ- 
ленні пацієнтів у приймальне відділення виконували трансабдомінальне ультразвукове дослідження (УЗД) органів черевної порожнини та заочеревинного простору. Згідно з локальними протоколами, проводили оглядову рентгенографію органів грудної клітки та органів черевної порожнини. У 57,9 \% хворих виконували ургентну ЕФГДС. Як правило, це були пацієнти з підозрою на супутню гастродуоденальну патологію та при сумнівах у встановленні діагнозу гострого панкреатиту.

Серед 65 пацієнтів першої групи у 80,0 \% під час трансабдомінального УЗД були чітко верифіковані специфічні зміни підшлункової залози та відсутність патологічних включень у спільній жовчній протоці. У 20,0 \% спостережень УЗД не дозволяло виключити патологічні зміни з боку позапечінкових жовчних протоків, що вимагало проведення у цих хворих МРТ. Серед пацієнтів другої групи, поряд з трансабдомінальним УЗД, 25,7\% потребували використання МРТ, а 74,3 \% - ендо- скопічної ретроградної холангіопанкреатографії (ЕРПХГ). Серед хворих третьої групи у 7,7 \% проведення тільки трансабдомінального УЗД дозволило нам виставити покази до ендоскопічної ревізії спільної жовчної протоки. Інші пацієнти цієї групи для верифікації причини гострого біліарного панкреатиту потребували застосування інших методів променевої діагностики.

Впродовж перших 24 годин лапароскопічна холецистектомія (ЛХЕ) була виконана у 49 пацієнтів $(75,4$ \%) першої групи (табл. 1). Ендоскопічні операційні втручання на великому дуоденальному соску та спільної жовчної протоки впродовж перших двох діб перебування в стаціонарі були проведені у 74,3 \% пацієнтів другої групи та 92,3 \% третьої групи. Метою ранніх ендоскопічних операцій було усунення обтурації великого дуоденального соска, термінальних відділів спільної жовчної та панкреатичної проток шляхом папілотомії, видалення конкремента тощо.

Таблиця 1

Характеристика операційних втручань у хворих на гострий біліарний панкреатит

\begin{tabular}{|l|c|c|c|}
\hline \multicolumn{1}{|c|}{ Вид операційного втручання } & $\begin{array}{c}\text { Перша група } \\
(\mathrm{n}-65)\end{array}$ & $\begin{array}{c}\text { Друга група } \\
(\mathrm{n}-35)\end{array}$ & $\begin{array}{c}\text { Третя група } \\
(\mathrm{n}-26)\end{array}$ \\
\hline ЛХЕ & $65(100.0 \%)$ & - & - \\
\hline ЕРПХГ + ЕПСТ & - & $4(11.4 \%)$ & - \\
\hline ЕРПХГ + ЕПСТ + екстракція конкрементів & - & $5(14.3 \%)$ & $12(46.2 \%)$ \\
\hline ЕРПХГ + ЕПСТ + ЛХЕ & - & $4(11.4 \%)$ & - \\
\hline $\begin{array}{l}\text { ЕРПХГ + ЕПСТ + екстракція конкрементів } \\
\text { ЛХЕ }\end{array}$ & - & $22(62.9 \%)$ & $14(53.8 \%)$ \\
\hline
\end{tabular}

У всіх пацієнтів з метою підготовки до операційного втручання проводили інтравенозну комплексну консервативну терапію, яка включала медикаментозну блокаду секреторної функцію підшлункової залози, детоксикацію шляхом форсованого діурезу, антибактеріальну профілактику та корекцію супутньої патології.

У пацієнтів з набряковим панкреатитом консервативна терапія дозволяла зменшити больовий синдром та стабілізувати гемодинаміку 3 достатнім погодинним діурезом впродовж 6-12 годин, що дозволяло значно мінімізувати ризик операції та знизити частоту після операційних ускладнень. У хворих 3 тяжким панкреатитом консервативна терапія проводилась в умовах відділенні інтенсивної терапії. Як тільки стабілізувався загальний стан цих пацієнтів, їм одразу виставляли покази до лапароскопічної холецистектомії та дренування черевної порожнини (перша група) або транспапілярної ревізії спільної жовчної протоки (друга і третя групи).

У хворих другої і третьої груп проводили ендоскопічну діагностику і ревізію позапечінкових жовчних шляхів 3 наступним проведенням ЛХЕ впродовж наступних 24 годин. Серед хворих цих груп, у 21 ЛХЕ була проведена в анамнезі. Тому у 4 пацієнтів $(11,4$ \%) другої групи була виконана тільки ЕРПХГ з ЕПСТ, а у 5 (14,3\%) вона доповнювалась екстракцією конкремента кошиком Дормia.

В післяопераційному періоді консервативна терапія базувалась на оцінці тяжкості стану пацієнта, вираженості проявів кардіоваскулярної, дихальної, ентеральної та печінково-ниркової дисфункції. Наявний перипанкреатичний інфільтрат вимагав включення в комплекс лікувально-діагностичних заходів антибактеріальної терапії карбапенемами та ультразвукового моніторингу черевної порожнини, підшлункової залози та заочеревинного простору кожні 3-5 днів.

Загальноприйнятим вважається, що перипанкреатичний інфільтрат при біліарному генезі панкреатиту перебігає легше і має нижчу частоту гнійнонекротичних наслідків. Серед пролікованих нами пацієнтів у 12 (9,5\%) виникали ускладнення, пов'язані 3 несприятливим перебігом запального процесу в підшлунковій залозі та перипанкреатичній клітковині. У 2 хворих першої групи, 3 - другої та 2 - третьої діагностували формування несправжніх панкреатичних кіст. Враховуючи їхній сприят- 
ливий перебіг та відсутність лабораторних та клінічних даних за їхнє інфікування, цим пацієнтам рекомендували в подальшому динамічне спостереження в амбулаторних умовах.

У 5 хворих формувались абсцеси заочеревинного простору (у 3 другої групи та у 2 - третьої). Ми не $\epsilon$ прихильниками широких лапаротомних доступів у пацієнтів 3 гнійними парапанкреатичними утвореннями. У цих хворих візуалізували топічну локалізацію абсцесу ультрасонографічно, після чого у одного 3 них абсцес був дренований шляхом пункції з встановленням дренажу типу pig tail, а у чотирьох - 3 поперекового доступу.

Висновки. 1. Діагностична тактика при гострому біліарному панкреатиті повинна включати, поряд з оцінкою біохімічного аналізу крові, визначення активності ліпази, $\alpha$-амілази, панкреатичної $\alpha$-амілази у сироватці крові, АСТІМ Pancreatitis тест, a інструментальне обстеження пацієнтів повинно включати МРТ панкреатогепатобіліарної зони, як проміжний етап між УЗД та ендоскопічною транспапілярною рентгенографією.

2. У пацієнтів з гострим біліарним панкреатитом слід дотримуватися активної хірургічної тактики, що передбачає ЛХЕ при холецистолітіазі та ендоскопічну транспапілярну декомпресію спільної жовчної протоки при холедохолітіазі в межах 24 годин перебування пацієнта у хірургічному стаціонарі.

Інформація про конфлікт інтересів. Автори заявляють про відсутність конфлікту інтересів при виконанні наукового дослідження та підготовці даної статті.

Інформація про фінансування. Автори гарантують, що вони не отримували жодних винагород в будь-якій формі, здатних вплинути на результати роботи.

Особистий внесок кожного автора у виконання роботи:

Василюк С.М. - концепція статті, формулювання висновків;

Шевчук А.Г. - корекція статті;

Іванина В.B. - набір матеріалу, підготовка статті до друку;

Гудивок В.I. - набір матеріалу, аналіз отриманих результатів;

Гуцуляк А.I. - аналіз отриманих результатів, статистична обробка;

Осадець В.С. - аналіз отриманих результатів, підготовка статті до друку.

\section{Список використаної літератури}

1. Gülen B, Dur A, Serinken M, Karcığlu Ö, Sönmez E. Pain treatment in patients with acute pancreatitis: A randomized controlled trial. Turk J Gastroenterol. 2016 Mar;27(2):192-6.

2. Ozkan Z, Gul E, Kanat BH, Gundogdu Z, Gonen AN. Is surgery safe in gallstone-related acute diseases in elderly patients? J Coll Physicians Surg Pak. 2016 Jun;26(6):471-5.

3. Barreiro AE, Mancebo MA, Varela TP. Readmissions due to acute biliary edematous pancreatitis in patients without cholecystectomy. Rev Esp Enferm Dig. 2016 Jul;22:108.

4. Sangrasi AK, Syed B, Memon AI, Laghari AA, Talpur KA, Qureshi JN. Laparoscopic cholecystectomy in acute gallstone pancreatitis in index hospital admission: feasibility and safety. Pak J Med Sci. 2014 May;30(3):601-5.

5. Vasylyuk SM, Ivanyna VV. Clinical and laboratory diagnosis of an acute biliary pancreatitis. Klinicheskaia khirurgiia. 2015 Feb;(2):32-4. [In Ukrainian]

6. Kuo VC, Tarnasky PR. Endoscopic management of acute biliary pancreatitis. Gastrointest Endosc Clin N Am. 2013 Oct;23(4):749-68.

7. Vasylyuk SM, Ivanyna VV. Diagnosis of Acute Biliary Pancreatitis. Ukrainian Journal of Surgery. 2016;1 2(30-31):60-3.

Стаття надійшла до редакції: 2.11.2017 p. 